the last occasion it did not come down to a satisfactory point till Dec. 9th. On Thursday, Dec. 11th, I found the patient changed. By this time the slough was removed. His face was livid and suffused, the veins standing out on his temples, and the temperature registered $104 \cdot 0^{\circ}$. There were moist crepitant sounds in the lungs. I administered a full dose of antipyrin, and by evening I had the watisfaction to see the temperature down to normal, and the patient looked his usual again. From that day the tem. perature has remained at normal or below it, and ere long the symptoms began to disappear-the cough, spit, sweating, \&c. - and in two weeks the bedsore was a large healing wound. The patient began to get back his appetite, and though stimulants were administered there was a return to strength. The patient geemed to pass through a stage of hyperæesthesia until he got fairly on the road to recovery. To bring the case to a conclusion, the wound has gone on slowly but steadily healing up, and with return of appetite the patient has gained strength and weight, so that now he is able to walk about the house. There has been no cough, and the patient has not been so well for many months. It has been pointed out that smallpox \&c. have been known to cure phthisis, and erysipelas has driven away lupus. I beg to place this case on record as a case cured by incipient septicœmia, for I can regard as no other these rises of temperature when the bedsore was covered in greater part with a black slough, and such was my diagnosis at the time when I saw the state of the wound. It would seem that some principle like sepsine was formed and circulated in the blood, and, reaching the tuberculous areas, acted as an antagonist to the disease and killed the tubercle bacilli. Hence the disappearance of the symptoms. Is it not possible that Koch's liquid may not be a genuine specific for phthisis, but merely one of the numerous fever agencies which bring about phenomena when they find a proper nidus in the organism? Whatever may be said, it is not the only agency which kills the tubercle bacilli and cures phthisis. It may be that this case I record will be of interest to those deeply versed in the etiology and cure of tuberculosis. I am, Sirs, your obedient servant,

Leith, N.B., Feb. 19th, 1891 . JaMeS W. MaRTiN, M D.

\section{THE TREATMENT OF PHTHISIS BY THE INHALATION OF SUPERHEATED AIR.}

\section{To the Editors of THE LANCET.}

SiRs -Dr. J. Cranstoun Charles in his article in THE LANCET on the above treatment of phthisis, after explaining the rationale of the method, proceeds to say: "Without going into the question of the temperature of this heated air when it reaches the lungs \&c." It is somewhat surprising that Dr. Charles did not remind your readers that there is very good evidence that air, at whatever temperature inhaled, reaches the lungs very slightly, if at all, above the temperature of the blood. By some experiments carried on at the Consumption Hospital, Brompton, the result of which I read betore the Clinical Society last session, this all-important point was pretty definitely settled.

"There was a patient under the care of Dr. Mitchell Bruce I with well-marked bronchiectatic excavation of the base of the left lung. Mr. Godlee had successfully tapped it after removing a piece of rib. On illuminating the interior of the cavity two openings could be distinctly seen, and a probe could be passed up them, and appeared to reach somewhere near the trachea, and caused coughing. Air passed very freely in and out of the cavity. When the patient inhaled peppermint it could be smelt at the wound, and when it was blown through the opening he almost instantaneously tasted it. This showed that there was a very free communication between the mouth and the cavity. Inspection of the lung, which was removed after death, clearly shows how very free this communication was. This patient was set to inhale hot air, which he did at about temperature of $300^{\circ} \mathrm{F}$. A thermometer was placed free in the cavity and carefully plugged in. At the end of one hour the thermometer only rose $1^{\circ}$. The patient thought it was a form of treatment which times, and always with the same result. Another case soon occurred which gave us further opportunities of trying experiments. A patient was admitted under the care of Dr Tatham, also with a cavity at the wase of the left lung. Its exact nature was never determined, as he fortunately made a complete recovery. It was tapped by Mr. Godlee after resecting a piece of rib. In this case also there was a free communication with the mouth, but not quite so free as in the preceding case, as he did not taste the peppermint quite so instantaneously. A probe could be passed up towards the trachea, which he said he felt, and it caused much coughing. The same experiments were repeated on him, but in his case the thermo. meter never rose at all. I think that these experiments show what most of us would have expected-viz, that the temperature of superheated air is rapidly dissipated in the mouth pharynx, and larger airtubes. These structures are extremely vascular, and the rapidity with which the blood circulates appears quite able to carry off any superfluous heat, and reduce the air to the normal temperature of the blood before it reaches the smaller bronchi and pulmonary tissue. It follows, then, that the inhalation of superheated air can have no influence over the course of phthisis."

Some experiments have also been made by Dr. Ernest Schowald of Jena on dogs, and the conclusions he came to were the same as my own. I. should not have troubled you with this communication but an inventor of one of these hot-air machines is actively advertising it

I am, Sirs, faithfully yours,

Brighton, March 9th, 1891.

H. H. TAYLOR.

\section{EMPYEMA OF THE ANTRUM.}

\section{To the Editors of THE LANCET.}

SIRs,-Dr. Hunter Mackenzie, in his interesting letter in your issue of the 7 th inst., tells us that, from his experience, it is rare to detect pus in the antrum without caries of the corresponding teeth. It is always instructive to have the opinion of so careful and trustworthy an observer; but $I$ think his statements would prove of even more value if he would give us some idea of the number of cases of empyema of the antrum he has observed and treated. Such a statement appears to me to be essential to the great question among rhinologists-viz, whether disesse of the teeth or some gross inflammatory affection of the nose is to be considered the commoner cause of suppuration in the antrum. In my forty cases I have never held a simple coexistent rhinitis to be responsible for the mischief, al though, as Dr. Mackenzie suggests, such is of ten apparently caused by the irritation of the septic discharge through the ostium maxillare. Nor do I consider it fair to assume that a coexistent carious tooth is necessarily the cause of the suppuration. We ought at least to have a periostitis of the fang, with suppuration around it, or penetration of the fang into the cavity above, before we can, on pathological grounds, assume that dental disease is responsible for the mischief. Unfilled carious teeth are so common among hospital patients that it is unusual to find no carious teeth in either a case of empyema of the antrum or any other disease. In fact, Sirs, I do not hesitate to affirm that the large majority of cases of nasal polypus, associated with a purulent discharge from the nose (I do not say mucopurulent), will be found to be associated with pus in the antrum; and, as I have remarked before, I believe it is the frequent coexistence of nose disease, which might in itself be considered sufficient to account for the suppuration without supposing the antrum to be involved, that explains wby so many cases of empyema of that cavity are overlooked. I am, Sirs, yours truly,

Harley-street, March 9th, 1891. GREvILLE MACDONALD.

\section{ETIOLOGY OF ENTERIC FEVER. To the Editors of THE LANCET.}

SIRs,--In December I was sent for to see a boy whose symptoms turned out to be those of typhoid fever. He is recovering, but a younger brother is now ill with the same complaint. Notice was given to the urban sanitary authority, and the medical officer of health visited the house where these patients live and found nothing amiss with its drainage or water-supply. For years there has not been a case of this fever in the town, and there is none existing in the neighbourhood. The boys have not been outside the town for many months. About the time when the boy first attacked was taken ill there had been occasional most unpleasant smells in the parish church, where he is a choir boy. Some thought the stench came from the sewer leading from the schools, and into which the church towerdrain pours; others maintained the smell was not sewer smell at all, but was due to mouldering Christians buried in and closely around the church. But as these two boys are the only individuals who have contracted typhoid fever, it would seem im. probable that the church smells were causative. No other guess has been hazarded as to the origin. The drinking water they used is that common to Trowbridge and many neighbouring villages, as well as this town. There is, and 
has been, no typhoid fever at the farm from which their milk is supplied. It would seem, then, as if the first of these cases had originated de novo; the second contracted from the first. - I am, Sirs, yours obediently,

Melksham, Wilts, Jan. 27th, 1891. ShMuel Girose.

\section{AMBULANCE CLASSES FOR THE MERCANTILE MARINE.}

To the Editors of THE LANCET.

SIRS,-I read with much interest the letter of Mr. C. H. Leet in THE LANCET of Feb. 28th, and I should be very glad to learn that the efforts of himself and those who are working with him meet with the encouragement they deserve, as there is no class to whom first-aid instruction is more necessary than the officers and men of the mercantile marine, especially those on board vessels which do not carry a doctor. Some years ago I assisted, on behalf of the St. John Ambu lance Association, in the inauguration of this work at Liverpool and other ports, but there was a very great difficulty in finding officers who could give sufficient time to attend the lectures, although the syllabus was altered and compressed to meet their special requirements. With regard to this subject, I received in 1882 a letter from the Marine Department of the Board of Trade, which contains the following paragraph:- "With reference to the correspondence, and to your recent interview, with officers of this department on the subject of the instructions of masters and mates in the mercantile marine, I am directed by the Board of Trade to acquaint you, for the information of the committee of the St. Joln Ambulance Association, that the Board of Trade, after careful consideration of the subject, are disposed so far to assist the Association in this matter as to authorise the placing by the Registrar-General of Seamen of an endorsement upon the certilicates of such officers as are reputed by the Association examiners to have passed successfully in this subject. I am, at the same time, to state that before conveying such authority to the RegistrarGeneral of Seamen they will require to have before them some further information as to the character of the instruction, and of the examination which will be employed, and of the arrangements generally, bearing in mind the limited time at the disposal of officers of the mercantile marine for acquiring knowledge of this kind."

This is such a valuable concession that $I$ am sure it will strengthen the hands of those who are now taking up this important matter. - I am, Sirs, yours faithfully,

Narch 4th, 1891. JOHN FURLEY.

\section{MEDICAL MIEN AND THE NOTIFICATION OF DISEASES ACT, 1889. \\ To the Editors of THE LANCET.}

SIRS,-The recentvexatious prosecution instituted against me by the vestry of Clerkenwell, which is fully reported in THE LANCET of the 7 th inst, shows the necessity and great advantage derived from belonging to such an institution as the Medical Defence Union. On my informing one of the hon. seeretaries (Dr. Bateman, of 64, Longridgeroad, S.W.) that a summons was abont to be issued against me, he immediately took steps for my defence, and neither trouble nor expense was spared to make the case a winning one. It frequently happens that medical men are saddled with heavy costs in defending their professional reputation and private character against unjust prosecutions, necessitating their appealing to their professional brethren for assistance; whereas, by belonging to this excellent Society, they would be saved much of the anxiety attending such prosecutions and the humiliating position of having to appeal under such circumstances.

I am, Sirs, your obedient servant,

Iarch 9th, 1891

F. L. MilburN.

\section{ERYSIPELAS AND TOTAL ABSTAINERS.}

To the Editors of THE LANCET.

SiRs,-My absence from England has prevented my taking notice before now of Dr. Ridge's letter in your issue of the 21st ult. He seems to have "run amuck" on the subject of alcohol generally. I do not see the point of his letter, and did not advocate the immoderate use of alcohol.
I am quite aware that alcohol in large doses, especially in the high temperature produced by disease, lowers the temperature of the body, but unaware that small doses of alcohol, well diluted, in health do so; in fact, the evidence goes to prove the contrary. The statistics he quotes on the rate of invaliding in India do not, I imagine, separate the moderate from the immoderate drinkers, and, if not, are worthless as far as the present question goes. Reference to any of the standard works on the subject will probably tell him why alcohol in small doses is classed as a heat-praducing agent. Dr. Parkes, who experimented largely on the subject of alcohol, found that a man in health could take about $2 \mathrm{oz}$. of pure alcohol daily without any deleterious effect, and the question I asked was whether, under certain conditions, it was not beneficial. I should recommend Dr. Ridge, instead of instituting fresh experiments, to study what is already known on the subject; his knowledge on this particular point seems to require, to say the least of it, revision. I regret that my absence abroad will for the present prevent my continuing this discussion, which promises to be both amusing and instructive.

I am, Sirs, yours faithfully,

Montreux, March 3rd, 1891.

H. R. WHITEHEAD.

\section{LIVERPOOL. \\ (From OUR OWN CORRESPONDENT.)}

Society for the Prevention of Cruelty to Children.

DURING the month of February the local Society for the Prevention of Cruelty to Children, which is the first of its kind, took up 62 new and 61 old cases, the former involving the welfare of 92 and the latter that of 72 children. Among the complaints were-4 of assault, 58 of general neglect, 1 of begging by night, 49 of selling at night, 40 of exposure, 8 of sleeping out, 4 of dangerous surroundings. Great efforts are being made to prevent children trading by night, a form of cruelty practised by many idle and vicious parents, who, instead of providing for their children, expect the latter to provide for them.

\section{Legislation for Midwives.}

There is a phase of the present controversy respecting midwives which appears to have ezcaped notice. Not many years ago the average hospital and workhouse nurse was a drunken, ignorant old hag. Without any legislation all that has been changed, hospitals and workhouses being now supplied with well-educated, thoroughly trained young women, many, indeed, being ladies in the strictest sense of the word. Moreover, private nursing has been developed to a most extraordinary extent, quite as greatly to the advantage of the rich as the improved hospital and workhouse nursing are to the poor. In Liverpool an attempt was made almost a century ago to improve the status of midwives by the aid of the Ladies' Charity, the midwives of which were previously trained and examined by the surgeons before being appointed to office. Later on the Lying-in Hospital carried on this educational process, extending it also to monthly nurses, whose position has greatly improved in recent years. But in this, as in other cities and towns, many women little, if any, better than the midwife of old, still practise among the poor, and among those who, not being poor, are still foolish enough to employ them. The records of our coroner's court within the last twenty years would furnish material enough to fill many columns of THE LANCET with sad illustrations of the fatal results caused by the ignorance and, what is worse, by the persistent recklessness of these women in refusing to send for medical aid when it is imperative. It is bad enough in large towns and cities, but what must it be in remote villages and hamlets far away from medical aid? Legislation is absolutely necessary to prevent ignorant and incompetent women from practising for gain to the danger of those women who employ them. A drunken old hag could not obtain a situation as nurse to a hospital or workhouse, but there is nothing to prevent her putting a brass plate with "Midwife" under her name on her door. In this simple fact lies the whole question to be solved.

The late Assistant Recorder of Liverpool.

Mr. Leofric Temple, Q.C., whose death occurred on the 6 th inst., was well known to the medical profession here, in London, and elsewhere. Formerly he was engaged as 